\title{
The Consequences of Information Technology, Information Sharing and Supply Chain Integration, towards Supply Chain Performance and Firm Performance
}

Author(s): Veera Pandiyan Kaliani Sundram, Prem Chhetri, Atika Shamsul Bahrin

Source: Journal of International Logistics and Trade 2020; 18(1):15-31

Published by: Jungseok Research Institute of International Logistics and Trade, Inha University

DOI: https://doi.org/10.24006/jilt.2020.18.1.015

The Journal of International Logistics and Trade is an official journal published by Jungseok Research Institute of International Logistics and Trade, Inha University, Korea. JILT welcomes manuscripts that advance the practice and science of logistics, trade, and other related fields.

Frequency: Quarterly (March, June, September, December)

Stable URL: https://www.ejilt.org

The Jungseok Research Institute of International Logistics and Trade is a specialized academic research institute representing Inha University and the Inha Foundation in Korea. The institute aims to become a representative institute in Northeast Asia in the research of logistics and trade.

Stable URL: https://jrieng.inha.ac.kr

(C) Copyright. Jungseok Research Institute of International Logistics and Trade.

This is an Open-Access article distributed under the terms of the Creative Commons Attribution NonCommercial License (http://creativecommons.org/licenses/by-nc/4.0/) which permits unrestricted noncommercial use, distribution, and reproduction in any medium, provided the original work is properly cited 


\title{
The Consequences of Information Technology, Information Sharing and Supply Chain Integration, towards Supply Chain Performance and Firm Performance
}

\author{
Veera Pandiyan Kaliani Sundram ${ }^{1,}{ }^{*}$, Prem Chhetri ${ }^{2}$, Atika Shamsul Bahrin ${ }^{3}$ \\ ${ }^{1}$ Department of Technology and Supply Chain Management Studies, Faculty of Business and Management, Universiti Teknologi MARA, Selangor, Malaysia \\ ${ }^{2}$ Global Supply Chain and Logistics Research Priority Area, School of Business IT and Logistics, RMIT University, Australia \\ ${ }^{3}$ Department of Postgraduate and Professional Studies, Faculty of Business and Management, Universiti Teknologi MARA, Selangor, Malaysia
}

$\begin{array}{lc}\text { Received } & \text { January 08, } 2020 \\ \text { Revised } & \text { January 25, } 2020 \\ \text { Accepted } & \text { March 12, } 2020 \\ & \\ \text { *Corresponding author: Veera Pandiyan } & \text { Kaliani Sundram } \\ \text { Department of Technology and Supply } \\ \text { Chain Management Studies, Faculty of } \\ \text { Business and Management, Universiti } \\ \text { Teknologi MARA, Selangor, Malaysia } \\ \text { Tel: +6012-2313979 } \\ \text { E-mail: veera692@uitm.edu.my }\end{array}$

Received January 08, 2020

Revised January 25, 2020

Accepted March 12, 2020

*Corresponding author: Veera Pandiyan Department of Technology and Supply Chain Management Studies, Faculty of Cusiness and Management, Universiti Tel: +6012-2313979

E-mail: veera692@uitm.edu.my

\begin{abstract}
This paper presents the concerns in manufacturing supply chain. Further this study investigates the role of information technology (IT) and information sharing (IS) in manufacturing supply chain and determines its impact towards supply chain integration (SCI), supply chain performance (SCP), and manufacturing firm performance (FP) in Malaysia. The theoretical framework was proposed for the study on the basis of existing literature. The study administered a survey questionnaire to collect data from manufacturing firms in Malaysia with 112 respondents. A multiple regression analysis is conducted to establish the relationship between IT, IS, SCI, and FP. The study finds that IT and sharing has significant positive effect towards and performance. Firms that use IT and practice IS across partners in the supply chain are more likely to integrate their internal and external value chain for better performance both within and across the manufacturing firms in the supply chain. This study can be of interest to the manufacturing industry as well as other industry practitioners interested in improving the performance of the organization and supply chain in total. For supply chain practitioners, this results indicate that the firms should adopt IT and IS practices to strategically improve SCI. This in turn will also improve the supply chain network and firm's performance. This study employs a newly developed framework which depicts the causal relationship between IT, IS, SCI, Supply Chain Performance, and FP in Malaysia. Furthermore, it closes a gap in existing literature by examining the effect IT and communication (ICT) practices toward manufacturing firms' performance and SCP in a single setting. In addition, the current study attempted to construct a model which would estimate and interpret SCP and FP simultaneously, and to evaluate this model in an empirical fashion.
\end{abstract}

Keywords Information technology, Information sharing, Supply chain performance, Supply chain integration, Firm performance

\section{Introduction}

Information Technology and Communication (ICT) has become an integral component of the supply chain which helps improve the organization's performance. ICT can also be considered as a technology-based component of information systems as posited by (Hollander et al. 1999), with a goal of establishing computerized information systems through the utilization of computer-based networks within an organization (Sarosa and Zowghi 2005). Carr and Smeltzer (2002) consider information technology (IT) as a platform for business connections, linking suppliers through the exchange of electronic data, establishing computer-to-computer connections with suppliers as well as systems of information. ICT is now characterized by rapid communication and greater competence levels to enhance supply chain efficiency. For example, in the container shipment transport, most widely implement IT systems to improve supply chain integration (SCI), information sharing (IS) and collaboration among supply chain partners (Lun et al. 2008; Wong et al. 2009). In addition, efforts to develop novel ICT tools namely e-shipping, e-customs, and other e-business applications indicate that IT and IS have many significant ramifications for businesses. Moreover, Thong and Yap (1995) assert that increased work productivity and supply chain cooperation is the target 
of utilizing IT in many corporations.

In Malaysia, the importance of ICT practices namely, IT implementation and IS practices are paramount to achieving the goal to accelerate its pace in industrialization towards attaining a developed nation status by Year 2040. Malaysia has been continuously investing in building IT infrastructure and management frameworks to drive IT-led innovations to enhance business processes and systems integration. However, there is few empirical studies (Sundram et al. 2018a; Sundram et al. 2016c) that have examined the effect of IT and sharing on supply chain performance (SCP) and firm performance (FP). The extent, scope and scale of these impacts on the wider supply chains across firms need to be understood in the era of globalization and digitalization, where organization performance is galvanized by the adoption and utilization of ICT. The integration and collaboration between firms in a supply chain are essential elements in shaping the FP (MIDA 2018).

The implications of IT and IS are manifold. Since ASEAN is a growing market for industrialization and consumerism, there is a strong need to widely adopt IT to enhance IS and improve SCP. Malaysia has been implementing a range of IT strategies the inception of multimedia super corridor in 1996, and therefore it provides a sound basis for testing these relationships. In addition, till date, there are only a few empirical studies (Sundram et al. 2016c; Sundram et al. 2018a) that modeled the effect of IT and sharing on SCP and its subsequent effect towards FP. The findings of these studies are yet to be empirically validated in countries like Malaysia which represents a transitioning state in the development process. Therefore, this study addresses the gap in the current body of knowledge by modeling the effect of IT on the performance both at a supply chain firm level.

The remainder of the study is organized as follows. Section 2 outlines the theoretical framework and hypotheses. Section 3 describes the methodology of this study, specifically the data collection and sampling method. Sections 4 describes the data analysis and reports the results. Section 5 and 6 presents the conclusions, implication and recommendation for future research, respectively.

\section{A theoretical framework}

IT refers to the software and hardware components of computer systems which allow for support and sustainability in the operating, management and strategizing within organizations (Thong and Yap 1995). Chen et al. (2011) highlight the mixed results from various studies that examined the consequences of its applications in improving SCP. It is posited that the adoption of IT itself is not the issue, but rather the way it is implemented and integrated by firms and their associates (Kim and Lee 2010).

IS is deemed to be crucial to Supply Chain Management (SCM) both theoretically and practically. IS is the ability to handle the movement of information through the supply chain (Shore and Venkatachalam 2003). In manufacturing activities, IT is primarily utilized to ensure a synchronized and computerized or non-manual basis for production on shop floors (Banker et al. 2006). Through links with other systems, manufacturing information can be passed around companies, customers and suppliers. In this way, suppliers can keep tabs on how their materials are being used in production processes while the customer is able to track the manufacturing operation of the goods they wish to purchase.

Studies (e.g., Nguyen et al. 2015; Prajogo and Olhager 2012; Subramani 2004; Thun 2010) have established that IT can successfully facilitate collaborative networks between firms, suppliers and customers. IT also enriches these collaborative networks by encouraging cross-functional relations between various parties within a supply chain. IT gets rid of restrictions between firms and between functional areas to ensure an effective flow of information. The integration of suppliers into joint planning ventures and the development of new goods is also encouraged through IT (McIvor et al. 2000). IS, which itself has evolved with new developments in IT, is a crucial component that contributes to SCP (e.g., Jharkharia and Shankar 2005; Lee and Whang 2000; Prajogo and Olhager 2012). On the other hand, insufficient resources for IS, due to inadequate funds or cognizance on the part of management, has been pinpointed as a serious obstacle in achieving optimal SCI (Bender 2000).

SCI is the level of integration between all processes carried out within an organization and its associated suppliers, partners and customers within a supply chain (Flynn et al. 2010; Narasimhan and Kim 2002; Rai et al. 2006; Stonebraker and Liao 2006). There are two levels of SCI, namely external integration with trade associates and internal integration in terms of functions. Forming a strong link between components such as inventory and shipping is an example of internal integration on the basis of functions (Trkman and Groznik 2006). External integration involves the physical passage of information from customers to manufacturers and on to the suppliers (Frohlich and Westbrook 2001; Schoenherr and Swink 2012). Short-term objectives include improved productivity and a decrease in lead time and inventory, while successful and effective integration is a major part of the long-term objectives ( $\mathrm{Li}$ et al. 2006; Lyons et al. 2004). This indicates how SCP can impact and be impacted by SCI. For example, companies in the same industry can apply various supply chain strategies in order to integrate 
processes and systems between various firms within the supply chain (Kim 2009; Li et al. 2006; Pramatari 2007). SCI is the close cooperation of multiple parties in a supply chain as they work together to ensure a smooth progression of information and goods from the supplier to the customer (Donk et al. 2008).

SCP is the methodical quantification of processes or concepts within the supply chain (Anand and Grover 2015; Sundram et al. 2016b). SCP can be measured through collaborative integration among firms or parties which make up supply chains (Garengo and Bititci 2007). Whalen (2002) explains how effective supervision of a supply chain's performance can help a company ascertain whether they are providing exemplary services and maintaining financial viability. Effective monitoring of the SCP helps guarantee consistent enhancement of the SCP (Milliken 2001). Chan and Qi (2003) assert that performance measurement should be holistic and inclusive with an emphasis beyond the boundaries of a company. All parties within a supply chain share the mutual goal of working together to cater to and satisfy customer demands with their services and products (Sundram et al. 2011). The performance of a supply chain must also be evaluated among organizations in a manner which allows for optimal worldwide performance across the supply chains (Sundram et al. 2016a).

FP is an assessment of the organization's performance not only on the basis of its individual capabilities and results, but also in the context of the market in which it exists. Evaluating FP faces many challenges which include inconsistency in selecting indicators and failures in reaching consensus (Combs et al. 2005; Crook et al. 2008; Richard et al. 2009). Much research has evaluated FP on a single index with a one-dimensional interpretation, despite the fact that results are often more nuanced (Miller et al. 2013). FP as a concept must be made distinct from organizational effectiveness in general. Firms must offer excellent service and meet the expectations of customers (Fornell et al. 1996). Greater customer satisfaction ensures higher inclination to pay for services and products and consequently increases the firm's value (Barney and Clark 2007). Brooks (2000) posits that the performance evaluation of a company should include surveys of customer satisfaction as well as customer complaints rates. Researchers (Barney 2000; Conner 1991; Teece 2012) highlight the importance of pinpointing one prominent characteristic of a firm which bolsters organizational performance. It is suggested that companies place more focus on shortterm accounting components and financial performance in order to enhance the management of knowledge-based systems (Collins and Hitt 2006). While financial indicators are a sign of a firm's economic objectives, financial performance alone is a limited area compared to non-financial indicators (Venkatraman and Ramanujam 1986). Neely et al. (2005) assert that a firm's performance evaluation is the measure of how efficient and effective an action taken by the organization.

Information distortion has a detrimental impact on performance and is a fundamental problem faced in SCM (Lee et al. 1997). IS is considered extremely important from both practical and theoretical standpoints, because it informs the basic ability to handle the movement of information within a supply chain (Shore and Venkatachalam 2003). IT is greatly beneficial in creating a successful and efficient process of IS (Wu et al. 2009). Smooth IS between parties in a supply chain requires solid infrastructure to be in place. There can be a disparity in the efficiency and scope of IS when the usage of IT among supply chain members is disproportionate to one another (Forster and Regan 2001). IT resources such as electronic interfaces with rapid connections boosts SCM cooperation by aiding IS activities (Akkermans et al. 2003). IT is heavily used in various stages of trade, including goods development and manufacturing.

IT is primarily utilized in manufacturing activities to ensure a synchronized and computerized or non-manual basis for production on shop floors (Banker et al. 2006). Through links with other systems, information related to the manufacturing process can be distributed among companies, customers and suppliers. In this way, suppliers can keep tabs on how their materials are being used in production processes while the customer is able to track the manufacturing operation of the goods they wish to purchase. The planning stages heavily rely on enterprise resources planning (ERP) systems which encourage the smooth transmission of IS and optimal distribution of resources in companies, as well as a host of additional processes within supply chains. Implementing components such as computer aided design (CAD), computer aided process planning (CAPP) and computer aided manufacturing (CAM) in the product development stage allows for the process to occur smoothly thanks to the existence of a mutually understood system (Boyer and Pagell 2000). This makes it more convenient to re-utilize older information and easier to make new designs based on existing plans. These IT-based resources significantly enhance communication and IS within a firm.

IS, which itself has evolved thanks for developments in IT, has been pinpointed as a crucial component in successful SCM (e.g., Jharkharia and Shankar 2005; Lee and Whang 2000). On the other hand, insufficient resources for IS, due to inadequate funds or poor preparation and lack of foresight on the part of management, has been highlighted as a significant obstacle in achieving optimal SCI (Bender 2000). The advantages of IS are higher sales rates, better ordering functions and improved inventory allocation resulting in decreased shortage costs. This is due to the fact that enhanced IS processes diminishes information distortions within the vertical portions of the supply chain. On the other hand, deficient infrastructure for IT creates 
major limitations in the effort to effectively reach SCI (Bender 2000).

There exists an extensive scope of problems related to suppliers and as such expertise is necessary in different functions across a firm (Anderson et al. 2014; Chen and Paulraj 2004; Jain et al. 2009). Teams are created with the specific purpose of catering to supplier development, depending on the materials being procured or the supplier's requirements, in this way allowing for interaction and communication (Hahn et al. 1990). This participation can involve minor or major responsibilities, ranging from giving suggestions to taking on the entire creation of a particular material component for production (Wynstra et al. 2000). IT has been proven to efficiently facilitate collaborative links among networks of companies, suppliers or customers. Grover and Malhotra (1997) also highlight how IT promotes collaboration by encouraging cross-functional links among the members of a supply chain. This minimizes borders between companies and between functional regions of a firm, allowing for seamless flow of information. This also encourages supplier integration in terms of joint planning and development of new goods (McIvor et al. 2000).

ICT practices is a key component in SCM. It makes it possible for companies to exchange greater amounts of more complex information with their trade associates. Through the use of IT, organizations can also offer concurrent updates and data related to schedules or delivery ( $\mathrm{Li}$ et al. 2009). Coordination between companies and suppliers and among firms is also made more efficient with the ability to plan and schedule. In these ways, issues in handling supply chain processes which can otherwise be compromised by distance and time are minimized (Paulraj and Chen 2007). The utilization of IT in supply chains has given rise to a range of new applications to facilitate communication in a business-to-business (B2B) context such as, BSB private (Ethernet) or electronic point of sale (EPOS). Research has indicated that efficient use of IT results in improved SCI, particularly with regards to the flow of materials (Soliman and Youssef 2001). As such, IT encourages crucial activities within supply chains, ranging from sourcing, obtaining materials and completing orders for products and services (Kehoe and Boughton 2001).

Hence, the following hypotheses were formulated:

H1. There is a positive relationship between information technology and information sharing.

H2. There is a positive relationship between information technology and supply chain integration.

H3. There is a positive relationship between information technology and supply chain performance.

The interpretations of SCI in literature include the complementary aspects shared by integration and IS. Relationships with other parties in the supply chain are significantly improved through integration, allowing organizational tactics, plans and activities to be shared between multiple firms in an aligned and synchronized process. SCI allows IS to occur through a gathering of resources and knowledge into a mutually accessible outlet for all parties in a supply chain. This indicates how IS is strengthened through the use of SCI as part of the infrastructure which encourages such sharing between participants in a supply chain.

IS necessitates the trading of strategic supply chain information beyond simply business agreements, such as transfer of materials or orders. Strategic supply chain information allows supply chain members to make tactical choices in their activities (Li et al. 2006a). This can foster relationships based on mutual trust, inclination to share and a sense of communal ties between supply chain members. This improves IS, results in longer contracts between partners in a supply chain, enhances flexibility and responsiveness towards customers, and creates an overall better environment for effectively managing conflict and exchanging information. This consequently results in stronger operations of the supply chain, where there are reliable longterm ties between important entities in the network and they are able to apply necessary solutions and resolve problems decisively.

The efficiency of a supply chain is proven to be impacted by IS conducted between companies and among supply chain members ( $\mathrm{Li}$ and Lin 2006; Li et al. 2006b; Madlberger 2009). The knowledge-focused indicators emphasize the extent of knowledge which expedites the operation of the supply chain (Ketchen and Giunipero 2004). Several studies focus on the SCP of IS that are supported through intra-integrative inter-and inter-relationships. The information is shared by the network from organizational forecasts to planning data and information products and processes (Barlow and Li 2005). Performance measurement in SCM allows for collaborative integration among the members of a supply chain. There are several approaches to assessing performance in a supply chain, including applying financial aggregates, consulting suppliers and customers, or using individual measures for evaluating performance (Van der Vaart and Van Donk 2008; Zhang et al. 2011). Metrics are crucial in the measurement of SCP (Gunasekaran and Kobu 2007).

Thus, the following hypotheses were proposed: 
H4. There is a positive relationship between information sharing and supply chain integration.

H5. There is a positive relationship between information sharing and supply chain performance.

Zailani and Rajagopal (2005) highlight how SCI incorporates various parties involved in the networks within a supply chain, including firms, suppliers and buyers. Lambert et al. (1998) and Lambert and Cooper (2000) identify SCM as the flow from suppliers to the final customers, incorporating the goods, services and information provided which contributes a value-added component to the end users and relevant stakeholders. Wu (2009) asserts that performance is positively impacted by SCI. A smoother flow of products and more transparent functions are made possible by the integrated supply chain which also minimizes the time taken between the receipt and delivery of customer orders (Hult et al. 2004). It is suggested that literature related to organizational performance be re-appraised.

FP is a vital component of performance measurement, due to the fact that generating profit on behalf of shareholders is the primary objective of a firm (Chen and Paulraj 2004). Some research on a limited basis has been carried out to provide theoretical and practical suggestions (Sahin and Robinson 2002) on ways to facilitate SCI in a manner which creates profit for the organization. Existing studies also provide a basis for financial performance and operational performance to be used as indicators for FP (Tan et al. 1998; Vickery et al. 2003).

SCI also increases the inclusion of customers into supply chain processes, consequently enhancing information flow among members of the supply chain. SCI also allows a company to become specialized within a particular scope and collaborate with other entities in the supply chain with different ranges of knowledge, expertise and resources (Sundram et al. 2018b). Alternatively, SCI refers to embracing and applying technologies and processes as well as cooperative platforms between parties in a supply chain. This results in the development of a smooth channel of exchange for materials, information and completed products. In this way, firms can strongly grasp other organizations' practices and provide help through sharing information, creating an improved level of SCP.

Thus, the following hypotheses were stated:

H6. There is a positive relationship between supply chain integration and supply chain performance.

H7. There is a positive relationship between supply chain integration and firm performance.

Firms which emphasize short-term accounting capabilities and financial performance will focus less on the capacity to manage knowledge (Collins and Hitt 2006). Literature by Slywotzky et al. (2000) and Zahra and George (2002) suggest that a firm's aggregate performance relative to its growth in sales revenue from existing products and from new products and markets (Ibrahim et al. 2010). SCP is a direct component in assessing FP. However, Collins et al. (2010) point out that enhanced levels of SCM was not reflected in the environment management capabilities of developed country-based industry, such as, US-food retailers.

Still, performance effects were gathered, analyzed and assessed in three areas through meta-analysis. The financial aspect of

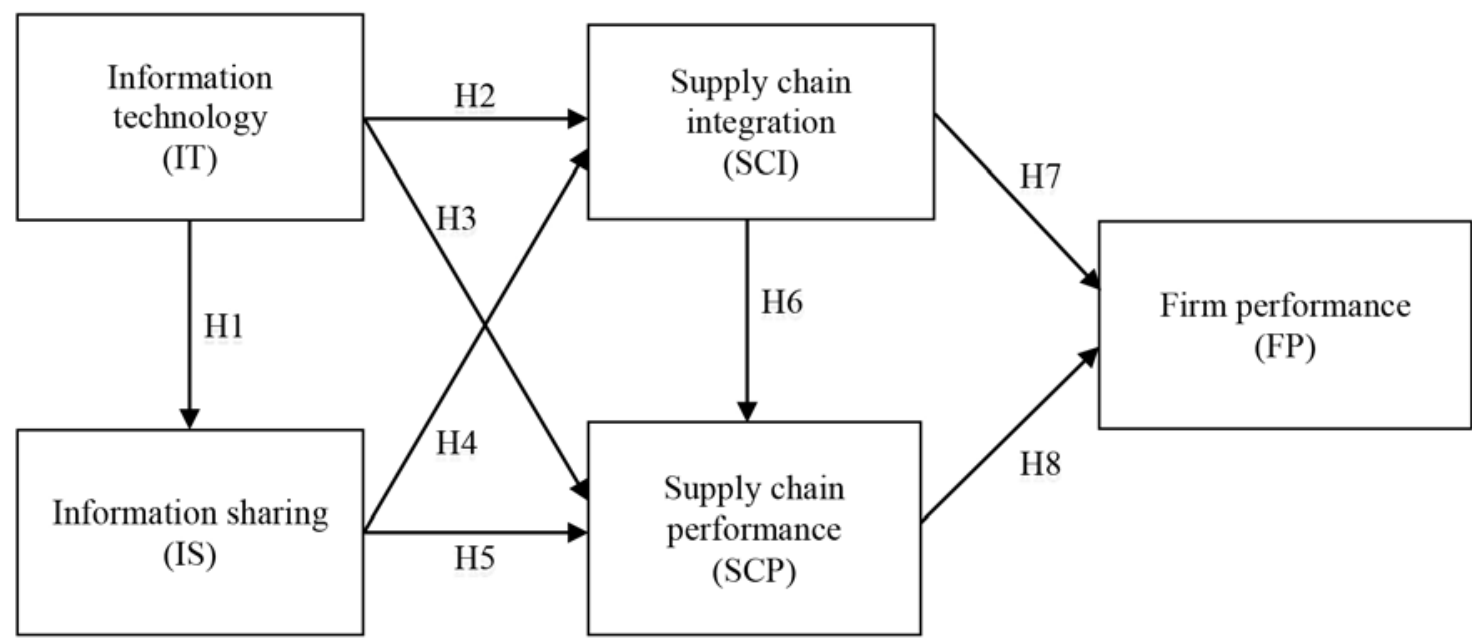

Figure 1. Theoretical framework and hypotheses. 
FP is evaluated on the basis of yields minus cost, while customer-based performance measures are related to customer loyalty and the firm's growth in ability to meet customers' requirements. The current study views FP in terms of marketing and financial performance. The emphasis is placed on how profitable the organization is and its rates of return on investment in the context of the average levels for that industry (Green and Inman 2005). SCP can be assessed through various methods, including single operational performance measures, aggregate financial measures, and consulting with suppliers and customers (Van der Vaart and van Donk 2008; Zhang et al. 2011). Prahinski and Benton (2004) highlight two streams which can be used to evaluate supplier performance, namely internal indicators and competitive factors.

Consequently, the following hypothesis was posited:

H8. There is a positive relationship between supply chain performance and firm performance.

\section{Methodology}

\subsection{Context of the study}

SCI has grown into a key issue within SCM and operational processes as a result of its important function in encouraging exchange and collaborative activities among companies globally. The operations performance correlation of SCI has been extensively researched in the literature for global supply chains and business management (Akmal et al. 2016). Academics have consistently emphasized the necessity of close and trusted bonds between members of a supply chain. The recent development of methodical strategies towards SCI puts pressure on companies to reassess their tactics regarding information integration. In the organization, SCI can be utilized across various functions, internal sections, and external trade associates. Zhao et al. (2008) and Zoliat et al. (2010) posit that external integration of a firm with suppliers and customers is made possible through internal integration first. A company must establish strong integration in its internal activities, data and other processes and then aim to achieve meaningful levels of external integration Zhao et al. (2011). IS can be utilized in supply chains for external and internal integration purposes.

The current study limits its scope to Malaysia, due to factors such as the necessity for effective communication within national industries and organizations, especially during variations in economic activity levels. Malaysian firms' ability to overcome global competition is crucial to our international opportunities, and research can aid in the efforts to establish Malaysian industries in the worldwide market.

\subsection{Data collection and sampling}

Questionnaires which were dispensed to various firms and other entities within the industry are collected and the responses gathered as data. The questionnaires focus on the relationships between IT, IS, SCP, and SCI and how this impacts FP among manufacturing companies in Malaysia. A total of 500 questionnaires were distributed, and respondents consist of managementlevel and other employees within the industry. The questionnaires are delivered through email and respondents provided answers on a self-evaluation. The entire respondents selected are experts in the area of operations management, supply chain and logistics management.

This study employs a "self-assessment questionnaire" approach for data collection purpose. Respondents will receive a questionnaire through e-mail and will fill out the questionnaire which elicit responses pertaining to IT, IS, SCI, SCP, and FP. A formal letter of genuine conformation and explanation of research study case with assured of confidentiality and anonymity towards participants on their returned questionnaires was included in the attached e-mail (Sundram et al. 2016b). There was correspondence through phone and e-mail as reminders were sent exactly a week after the first mail attempt. This study chooses this approach when researchers can reach respondents via phone and/or e-mail when they are willing to interact.

A total of 112 questionnaires were collected and fully completed at the end of the data collection period, indicating a respond rate of 37.33 percent. Demographic factors include gender, age, academic qualifications, professional status and marital status. From the analysis of Table 1, it is discovered that the male respondents (56.3 percent) contributed more in participating in this survey as compared to female respondents (43.7 percent). From the total of 112 respondents who participated in this survey, it is shown that most of the respondents involved are between the two different age that have same result which is 20-25 and 2630 years old, which represents the distribution at the frequency of 28 respondents ( 25 percent) and the least respondents are from the age 36-40 years old which is 16 respondents (14.3 percent). The rest of the respondents are from the age 31-35 years old which is 21 respondents (18.8 percent) and the age 41-45 years old which is 19 respondents (16.9 percent). It is shown that 
Table 1. Characteristics of respondent

\begin{tabular}{|c|c|c|c|}
\hline Demographic variables & Category & Frequency & Percentage (\%) \\
\hline \multirow[t]{2}{*}{ Gender } & Male & 63 & 56.3 \\
\hline & Female & 49 & 43.7 \\
\hline \multirow[t]{5}{*}{ Age } & $20-25$ & 28 & 25.0 \\
\hline & $26-30$ & 28 & 25.0 \\
\hline & $31-35$ & 21 & 18.8 \\
\hline & $36-40$ & 16 & 14.3 \\
\hline & $41-45$ & 19 & 16.9 \\
\hline \multirow[t]{2}{*}{ Academic qualification } & Bachelor & 81 & 72.3 \\
\hline & Master & 31 & 27.7 \\
\hline \multirow[t]{2}{*}{ Professional status } & Self-employed & 15 & 13.4 \\
\hline & Employed & 97 & 86.6 \\
\hline \multirow[t]{2}{*}{ Marital Status } & Married & 48 & 42.9 \\
\hline & Unmarried & 64 & 57.1 \\
\hline
\end{tabular}

$n=112$.

the bachelor's degree holder is the qualification with the most returned questionnaire which is 81 (72.3 percent) followed by master's degree holder 31 (27.7 percent) over the 112 respondents involved. The respondents who have answered this survey that has already employed represents the distribution at 97 personnel (86.6 percent). Whereas, for self-employed is only 15 personnel (13.4 percent) of the number of distributions. Also, it was discovered that the unmarried contributed more in participation for this survey as compared to those that have married. This shown by the questionnaire answered by all the 112 respondents which stated 64 respondents (57.1 percent) are unmarried and 48 respondents (42.9 percent) are married.

\subsection{Measurement assessment}

The current study attempted to construct a model which would estimate and interpret SCP and FP simultaneously, and to evaluate this model in an empirical fashion. Table 2 outlines the operational definitions utilized in this study, which were sourced from the relevant literatures. After observation and analysis, the Likert scale was deemed to be the most suitable scale for use in this study. To the greatest possible extent, all scale items which assess constructs were developed on the basis of those found in existing research. This approach was devised by Rensis Likert on account of its simplicity and convenience of use. The items on the current scale were scored on a seven-point Likert scale measuring from 1 (very disagree) to 7 (very agree). The Likert scale is easy for respondents to answer the questionnaire and also in measuring their survey art to IT, IS, SCI, SCP, and FP. This is where respondents find it easy to understand the scale used and making it ideal for mail survey.

The internal consistency and convergent and discriminant validity of the measurement model were assessed. Table 3 shows the results for average variance extracted (AVE) and composite reliability (CR) of the constructs. The results shown in Table 4 indicates the CR values of the factors which are 0.837 (IT), 0.903 (IS), 0.860 (SCI), 0.899 (SCP), and 0.953 (FP), all exceeding the recommended threshold values of 0.7 (Hair et al. 2016).

Meanwhile, the AVE values for all the constructs value at 0.510 (IT), 0.609 (IS), 0.606 (SCI), 0.645 (SCP), and 0.802 (FP), which indicated that all the values were higher than the cut-off value of 0.5 (Bagozzi and Yi 2012). Additionally, discriminant validity was examined using the square root of the AVE and cross-loadings as recommended by Fornell and Larcker (1981). As shown in Table 3, the AVE square root values were greater than the correlation with other latent variables, which suggest discriminant validity in the model (Fornell and Larcker 1981).

In order to test and provide support for the explanation of the results of all hypotheses, the significance of the path coefficient estimates in the model was examined (Figure 1 and result in Figure 2). To confirm the significance of a relationship, the $t$-value of the variables must be greater than 1.96. A bootstrap non-parametric procedure to test coefficients for their significance was used (Hair et al. 2016; Tenenhaus et al. 2005). The bootstrap samples for bias which number 5000, along with corrected intervals for bootstrap confidence and the 95 percent confidence rate were deemed to dominate the model (Hair et al. 2014). Hypotheses were accepted or discarded based on confidence intervals. As such, where a confidence interval value for a predicted coefficient excludes zero, it is assumed to have a significant impact. 
Table 2. Construct definitions and measures

\begin{tabular}{|c|c|c|c|c|c|}
\hline Construct & Description & $\begin{array}{l}\text { Item } \\
\text { code }\end{array}$ & Items & $\begin{array}{l}\text { Items } \\
\text { loadings }\end{array}$ & Source \\
\hline \multirow{5}{*}{$\begin{array}{l}\text { Information } \\
\text { technology } \\
\text { (IT) } \\
{[\alpha=0.769]}\end{array}$} & \multirow{5}{*}{$\begin{array}{l}\text { With the development of } \\
\text { technology, adopting IT } \\
\text { applications for the } \\
\text { purpose of moving } \\
\text { messages and fostering a } \\
\text { greater degree of } \\
\text { seamlessness in transport } \\
\text { service has become } \\
\text { common in container } \\
\text { shipping due to the } \\
\text { institutional pressure } \\
\text { exerted by supply chain } \\
\text { partners. }\end{array}$} & IT1 & $\begin{array}{l}\text { My firm actively instructs customers about how to use } \\
\text { electronic commerce web sites. }\end{array}$ & 0.757 & \multirow{5}{*}{$\begin{array}{l}\text { Lun et al. } \\
\text { 2008; Makris } \\
\text { et al. 2008; } \\
\text { Wong et al. } \\
2009\end{array}$} \\
\hline & & IT2 & $\begin{array}{l}\text { My firm adopts a customer relationship management } \\
\text { (CRM) system to collect market information and analyze } \\
\text { it. }\end{array}$ & 0.793 & \\
\hline & & IT3 & $\begin{array}{l}\text { My firm web site system can help integrate our supply } \\
\text { chain partners. }\end{array}$ & 0.623 & \\
\hline & & IT4 & $\begin{array}{l}\text { Customers frequently use my firm's web site to book space } \\
\text { for containers online. }\end{array}$ & 0.573 & \\
\hline & & IT5 & $\begin{array}{l}\text { My firm adopts online transactions to reduce operational } \\
\text { costs. }\end{array}$ & 0.795 & \\
\hline \multirow{6}{*}{$\begin{array}{l}\text { Information } \\
\text { sharing (IS) } \\
{[\alpha=0.875]}\end{array}$} & \multirow{6}{*}{$\begin{array}{l}\text { Among the little research } \\
\text { on remanufacturing with } \\
\text { IS, analyze the role of } \\
\text { information screening } \\
\text { contract and government } \\
\text { intervention on the CLSC } \\
\text { when the retailer shares } \\
\text { his collection effort level } \\
\text { with the manufacturer. }\end{array}$} & IS1 & $\begin{array}{l}\text { Organization informs its trading partners in advance of } \\
\text { changing needs. }\end{array}$ & 0.789 & \multirow[t]{6}{*}{ Li et al. $2006 b$} \\
\hline & & IS2 & $\begin{array}{l}\text { Organization’s trading partners share proprietary } \\
\text { information with your organization. }\end{array}$ & 0.685 & \\
\hline & & IS3 & $\begin{array}{l}\text { Organization's trading partners keep your organization } \\
\text { fully informed about issues that affect its business. }\end{array}$ & 0.777 & \\
\hline & & IS4 & $\begin{array}{l}\text { Organization's trading partners share business knowledge } \\
\text { of core business processes with your organization. }\end{array}$ & 0.777 & \\
\hline & & IS5 & $\begin{array}{l}\text { Organization and its trading partners exchange information } \\
\text { that helps establishment of business planning. }\end{array}$ & 0.853 & \\
\hline & & IS6 & $\begin{array}{l}\text { Organization and its trading partners keep each other } \\
\text { informed about events or changes that may affect the } \\
\text { other partners. }\end{array}$ & 0.792 & \\
\hline \multirow{4}{*}{$\begin{array}{l}\text { Supply chain } \\
\text { integration } \\
\text { (SCI) } \\
{[\alpha=0.781]}\end{array}$} & \multirow{4}{*}{$\begin{array}{l}\text { The level of integration of } \\
\text { core processes across } \\
\text { organizational boundaries } \\
\text { through improved } \\
\text { communication, } \\
\text { partnership, partnership } \\
\text { and cooperation. }\end{array}$} & SCI1 & $\begin{array}{l}\text { Firms in our supply chain establish more frequent contact } \\
\text { with each other. }\end{array}$ & 0.745 & \multirow[t]{4}{*}{ Power 2005} \\
\hline & & SCI2 & $\begin{array}{l}\text { Firms in our supply chain create a compatible } \\
\text { communication and information system. }\end{array}$ & 0.690 & \\
\hline & & $\mathrm{SCI} 3$ & $\begin{array}{l}\text { Our firm extends its supply chain beyond its } \\
\text { customers/suppliers. }\end{array}$ & 0.848 & \\
\hline & & SCI4 & $\begin{array}{l}\text { Our firm participates in the marketing efforts of its } \\
\text { customers. }\end{array}$ & 0.822 & \\
\hline \multirow{5}{*}{$\begin{array}{l}\text { Supply chain } \\
\text { performance } \\
\text { (SCP) } \\
{[\alpha=0.856]}\end{array}$} & \multirow{5}{*}{$\begin{array}{l}\text { Systematic process of } \\
\text { effectively and efficiently } \\
\text { quantifying a concept or } \\
\text { an action. }\end{array}$} & SCP1 & More accurate costing. & 0.743 & \multirow{5}{*}{$\begin{array}{l}\text { Anand and } \\
\text { Grover 2015; } \\
\text { Neely et al. } \\
2005\end{array}$} \\
\hline & & SCP2 & Increase in coordination between departments. & 0.921 & \\
\hline & & SCP3 & Increase in coordination with suppliers. & 0.917 & \\
\hline & & SCP4 & Increase in coordination with customers. & 0.565 & \\
\hline & & SCP5 & Increase in sales. & 0.817 & \\
\hline \multirow{5}{*}{$\begin{array}{l}\text { Firm } \\
\text { performance } \\
(\mathrm{FP}) \\
{[\alpha=0.938]}\end{array}$} & \multirow{5}{*}{$\begin{array}{l}\text { The firm performance } \\
\text { assessment should } \\
\text { consider customer } \\
\text { satisfaction surveys, } \\
\text { process reviews and } \\
\text { measurement of customer } \\
\text { complaint levels. }\end{array}$} & FP1 & $\begin{array}{l}\text { My firm's market share growth is higher than that of our } \\
\text { major competitors. }\end{array}$ & 0.857 & \multirow[t]{5}{*}{ Brooks 2000} \\
\hline & & FP2 & $\begin{array}{l}\text { My firm's total cost reduction is better than that of our } \\
\text { major competitors. }\end{array}$ & 0.908 & \\
\hline & & FP3 & $\begin{array}{l}\text { My firm's ability to answer customer questions is faster } \\
\text { than that of our major competitors. }\end{array}$ & 0.913 & \\
\hline & & FP4 & $\begin{array}{l}\text { My firm's customer satisfaction is better than that of our } \\
\text { major competitors. }\end{array}$ & 0.851 & \\
\hline & & FP5 & $\begin{array}{l}\text { Our customer loyalty is better than that of our major } \\
\text { competitors. }\end{array}$ & 0.945 & \\
\hline
\end{tabular}


Table 3. Convergent and discriminate validity

\begin{tabular}{lccccccc} 
& AVE & CR & IT & IS & SCI & SCP & \\
IT & 0.510 & 0.837 & 0.714 & & & & \\
IS & 0.609 & 0.903 & 0.323 & 0.780 & & & \\
SCI & 0.606 & 0.860 & 0.543 & 0.581 & 0.779 & 0.803 & \\
SCP & 0.645 & 0.899 & 0.518 & 0.710 & 0.778 & 0.645 \\
FP & 0.802 & 0.953 & 0.533 & 0.573 & 0.690 & 0.896 \\
\hline
\end{tabular}

Italic numbers on the diagonal show the squared root of AVE.

AVE, average variance extracted; CR, composite reliability; IT, information technology; IS, information sharing; SCI, supply chain integration; SCP, supply chain performance; FP, firm performance.

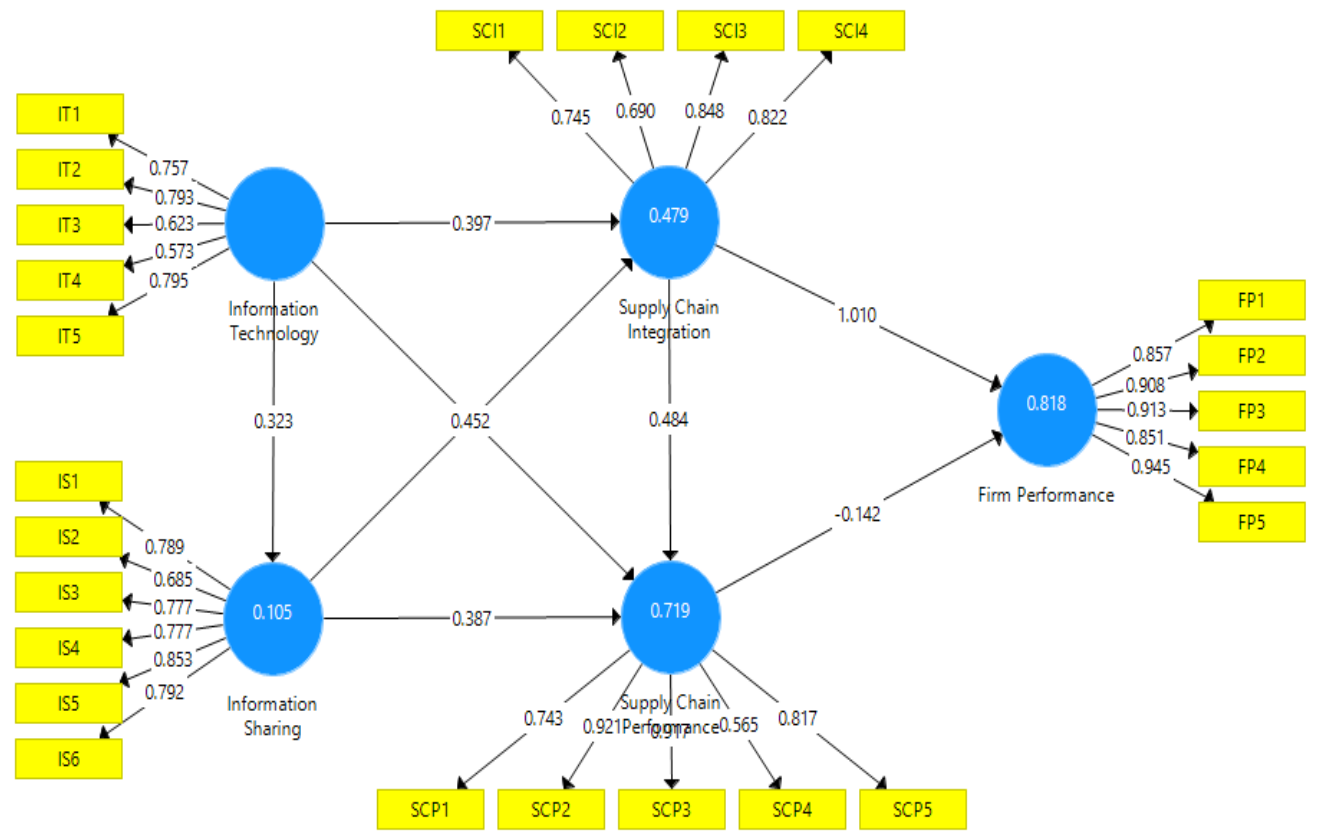

Figure 2. Structural model.

Hair et al. (2017) posit that researchers make note of the coefficient of determination $\left(R^{2}\right)$, and predictive relevance $\left(\mathrm{Q}^{2}\right)$ and effect size $\left(f^{2}\right)$ in addition to elaborating on the significance of relationships between the variables. In compliance with this, $R^{2}$, $f^{2}$ and $Q^{2}$ values were investigated and $f^{2}$ is outlined in Table 5. The $R^{2}$ refers to the explanatory abilities of the independent variable in the context of its associated dependent variables. The value of $R^{2}$ in Figure 2 shows that the IT explain 10.5 per cent of IS $\left(R^{2}=0.105\right)$, IT and IS explain 47.9 per cent of SCI $\left(R^{2}=0.479\right)$, IT, IS and SCI explain 71.9 per cent of SCP $\left(R^{2}=0.719\right)$, and IT, IS, SCI, and SCP explained 81.8 per cent of their FP $\left(R^{2}=0.818\right)$.

Next, $f^{2}$ indicates effect size; how much an independent variable contributes to the dependent variable's $R^{2}$. Cohen (1992) provided cut-off values for measuring effect size: $f^{2}=0.02,0.15$, and 0.35 , indicative of small, medium and large effect sizes, respectively. The results of $f^{2}$ indicate that IT have small to medium effect on both IS $\left(f^{2}=0.117\right)$ and SCP $\left(f^{2}=0.042\right)$, while a medium to large effect on SCI $\left(f^{2}=0.271\right)$. Whereas, IS have large effect on both SCI $\left(f^{2}=0.351\right)$ and SCP $\left(f^{2}=0.353\right)$. Same goes to SCI, which have large effect on both SCP $\left(f^{2}=0.433\right)$ and FP $\left(f^{2}=2.203\right)$. Lastly, SCP has a small to medium effect on $\mathrm{FP}\left(f^{2}=0.043\right)$.

\section{Results and discussion}

Table 4 shows the results of all direct effects for the hypothesized model concerning the relationships among IT, IS, SCI, SCP, and FP.

The research results confirmed that IT had a significant effect on IS is found in this research having path coefficient, $\beta=$ 0.323 and $t$-value $=3.751$ at $p<0.001$ significant level (LL: 0.166, UL: 0.499). This result suggests that the usage of IT in 
manufacturing industry is positively related with the spread of IS network especially in the usage of forwarding and receiving message and communication standards. Thus, IT and IS have a positive relationship and $\mathbf{H 1}$ is supported. Smooth flow of IS processes also allows the firm to effectively deal with unexpected demands through a well-established IT system which can offer the full scope of necessary information. The IT resources can illustrate the current condition of the supply chain, ranging from the inventory levels of both suppliers and manufacturers and the status of logistical facilities (Ngai et al. 2011).

Furthermore, a statistical positive relationship between IT and SCI is found in this research having path coefficient, $\beta=0.397$ and $t$-value $=4.683$ at $p<0.001$ significant level (LL: 0.166, UL: 0.499). Consequently, leads to the conclusion that the usage of IT would benefit greatly in SCI whether it is in upstream or downstream integration. Thus, in the research results, $\mathbf{H} 2$ supports the prediction of IT has a positive relationship with SCI. Li (2015) asserts that IT would efficiently manage the processes related to both upstream and downstream members throughout the supply chain. Effective IT management is also a key element in reaching SCI and establishing optimal trade processes between firms.

Based in Table 4 the results also support H3, which indicate that IT has a positive relationship with SCP. The research results showed that with the path coefficient $\beta=0.130$ and $t$-value of 2.071 at $p<0.05$ significant level, with a Lower Level and Upper Level of 0.010 and 0.254 respectively. This result indicates that if IT increases, the SCP of the organization will also improve. Prajogo and Olhager (2012) reinforce the finding that optimal SCP is achieved through the creation of data and sharing of information throughout the supply chain. Ngai et al. (2011) also posit that top management levels should be directly involved in planning IT strategies to improve the agility of the supply chain, and subsequently improve SCP.

Moreover, $\mathbf{H} 4$ theorized that IS has a positive effect on SCI and thus, is supported by this study's data results. The path coefficient between the two constructs was $\beta=0.452$ with $t$-value of 5.564 at $p<0.001$ significant level, with a Lower Level and Upper Level of 0.298 and 0.616 respectively. The statistical positive relationship indicates that high IS activities would encourage high demand in SCI. SCI and IS also contribute greatly to the flow of finances and physical materials. Strongly integrated IS structures allows various members of both the upstream and downstream supply chain to obtain operational data from different departments or areas of function. Suppliers, for example, can coordinate their delivery schedules by acquiring inventory data from their customers and planning accordingly.

Furthermore, there is also a statistical positive relationship between IS and SCP. It is found in Table 6, where the result show path coefficient, $\beta=0.387$ and $t$-value $=4.985$ at $p<0.001$ significant level (LL: 0.233 , UL: 0.538 ). Consequently, leads to the conclusion that the usage of IS would provide advantages in increasing the SCP of the manufacturing firm. Thus, in the research results, $\mathbf{H} 5$ supports the prediction of IS has a positive relationship with SCP. When the efficient flow of information within a supply chain is emphasized over the transfer of products and materials, the reduction of inventory and effective utilization of resources becomes attainable (Graham and Hardaker 2000). These days, inventory can be restocked promptly and conveniently through the communications-based resources provided by IS networks. Sezen (2008) highlights how reduced order cycle times and decreased inventory costs are made possible by exchanging information regarding supply and demand with the rest of the supply chain. IS and organizing also improve the supply chain's capacity to handle unexpected demands within an unpredictable market (Lee et al. 2000). As such, the general efficiency of a firm's SCP is significantly enhanced by collaborative IS among parties within that supply chain.

Besides that, the results also support H6, which indicate that SCI has a positive relationship with SCP. The research results

Table 4. The result of structural model assessment

\begin{tabular}{|c|c|c|c|c|c|c|}
\hline Hypotheses & Path & $\beta$ & $t$-value & CI (LL, UL) & $f^{2}$ & Results \\
\hline H1 & $\mathrm{IT} \rightarrow \mathrm{IS}$ & 0.323 & $3.751^{* *}$ & $0.166,0.499$ & 0.117 & Supported \\
\hline$H 2$ & $\mathrm{IT} \rightarrow \mathrm{SCI}$ & 0.397 & $4.683^{* *}$ & $0.219,0.552$ & 0.271 & Supported \\
\hline H3 & $\mathrm{IT} \rightarrow \mathrm{SCP}$ & 0.130 & $2.071^{*}$ & $0.010,0.254$ & 0.042 & Supported \\
\hline H4 & IS $\rightarrow$ SCI & 0.452 & $5.564^{* *}$ & $0.298,0.616$ & 0.351 & Supported \\
\hline H5 & $\mathrm{IS} \rightarrow \mathrm{SCP}$ & 0.387 & $4.985^{* *}$ & $0.233,0.538$ & 0.353 & Supported \\
\hline H6 & $\mathrm{SCI} \rightarrow \mathrm{SCP}$ & 0.484 & $5.423^{* *}$ & $0.298,0.650$ & 0.433 & Supported \\
\hline H7 & $\mathrm{SCI} \rightarrow \mathrm{FP}$ & 1.01 & $12.161^{* *}$ & $0.864,1.193$ & 2.203 & Supported \\
\hline H8 & $\mathrm{SCP} \rightarrow \mathrm{FP}$ & -0.142 & 1.340 & $-0.364,0.052$ & 0.043 & Not supported \\
\hline
\end{tabular}

${ }^{*} p<0.05,{ }^{* *} p<0.001$.

CI, confidence interval; LL, lower level; UL, upper level; IT, information technology; IS, information sharing; SCI, supply chain integration; SCP, supply chain performance; FP, firm performance. 
showed that with the path coefficient $\beta=0.484$ and $t$-value of 5.423 at $p<0.001$ significant with a Lower Level and Upper Level of 0.298 and 0.650 respectively. This result indicates that the increases in SCI will lead to an increase in SCP of the manufacturing organization. Information processing theory (IPT) proves that SCI provides management with an advantage in decision making and communicating with both internal staff and external collaborators. As such, the SCP is very reliant upon the extent of SCI. Additionally, Li (2015) points out that SCI allows firms to access necessary information regarding strategies, technology, demands and capacity in order to monitor the company's activities and cut down on wastage.

Correspondingly, $\mathbf{H 7}$ is where the prediction of SCI has a positive relationship effect on FP. It is also supported in the results of this study which indicate that the path coefficient was $\beta=1.01$ with $t$-value of 12.161 at $p<0.001$ significant level, with a Lower Level and Upper Level of 0.864 and 1.193 respectively. The involvement of SCI strengthens their intention to increase their manufacturing company's FP. SCI would guarantee the effective process of knowledge sharing, which cultivates the procurement of new information sourced from both internal and external integration and subsequently enhance FP. Internal integration helps secure the quality of goods and eliminate repetitive or redundant processes by efficiently utilizing the firm's own resources and capacities (Flynn et al. 2010). Effective levels of internal integration allow manufacturers to conduct more prompt deliveries of orders. Greater precision in predicting customer demands also facilitates production planning and cuts down on inventory costs (Swink et al. 2007).

However, the result in Table 5 shows that there is an insignificant relationship between SCP and FP. A statistical result of the path coefficient $\beta=-0.142$ and $t$-value of 1.340 at $p>0.05$ level, with a Lower Level and Upper Level of -0.364 and 0.052 respectively. Hence, conclude that $\mathbf{H 8}$ is not supporting the prediction of having a high SCP will lead to a much greater FP. An existing study by Li et al. (2006) posits that a strong relationship between FP and SCP must be achieved through integration. This will result in greater sensitivity to fluctuations in the market and changing customer demands. The organization will gain advantages in terms of enhanced achievements in terms of quality of goods, production costs and delivery times.

\section{Implications}

The outcomes of this study have significant implications that translate into a series of recommendations for the manufacturing firms' practitioners and managers in the area of operations, logistics and supply chain. This study presents the importance and use of ICT to communicate with different supply chain partners in the manufacturing industry. The research work contributes to an appropriate understanding to the professional working in the field of manufacturing supply chain.

The managers and executives nowadays are not only looking for performance improvement within their organization but also across their supply chain. This is due to the fact, IT and IS are prevalent to enhance inter-organization integration and performance. The research work provides three important managerial outlooks toward effective ICT practices which includes both IT implementation and IS practices, SCI and performance improvement. Firstly, it demonstrates that IT and IS are the important driver for manufacturing firms in disseminating timely and quality information with partners of the manufacturing supply chain across the region such as its suppliers, logistics providers, distributors, sub-contractors, network integrators, financial intermediaries and business customers, whom are geographically dispersed across ASEAN countries. Secondly, the network and information flow through ICT helps the movement of material and inventory from higher tier suppliers to various end users with the support of 3PL. The use of ERP, online procurement management system (OPMS) and customer relationship management (CRM) enables manufacturing firms to facilitate in achieving the desired degree of integration across the manufacturing supply chain. On the basis of these arguments, it may thus be stated that it is important for manufacturing firms to invest in the adoption and use of ICTs to build up their organizational capabilities and serve the upstream and downstream in a better manner. Lastly, the organization needs to employ adaptive IT and IS practices so that the desired level of interorganization integration and performance can be achieved. In the present scenario, it is considered that the competition is not among organizations, but among supply chains. As such, the findings of this research assure practitioners that ICT which promotes SCI can be an effective way to become competitive and eventually enhance performance. The study contributes toward enhancing the existing literature on manufacturing supply chain in terms of IT, IS, SCI and performance in both supply chain and frim level.

\section{Conclusion and future research}

In conclusion, the result of the study can facilitate the decision-makers in the manufacturing supply chain field to understand the importance of the association between IT, IS SCI, SCP, and FP measures. The study captured the main research question 
with the help of a thorough review of the literature. The literature pertaining to IT, IS, SCI and its impact on the performance of the organizations and supply chain were reviewed and synthesized to better understand the theoretical relationship. The results indicate that implementation of IT, IS, SCI is significantly associated with both firm and SCP. These findings are in conformance with the previous studies (Akmal et al. 2016; Ibrahim et al. 2010; Li et al. 2015). This study also further reveals that SCP has insignificant effect toward FP which contradict to the previous studies (Kim et al. 2010; Lee et al. 2000; Li et al. 2006). The results of this study is crucial for the growth of manufacturing industry in Malaysia, since they represent the relationship between IT, IS, SCI and its impact on the manufacturing SCP. These constructs should be considered when strategies are formed or implemented for the growth of the manufacturing firms to sustain in the present competitive environment. As such, the result could be used as an effective guide by managers across manufacturing supply chain for decision making processes. Overall, these research works enrich the existing literature through different outlooks of the relationships between ICT practices, SCM integration and performance measures. Although the study contributed toward the area of ICT and SCM, there are few limitations. The study used only IT and IS as the dimension for ICT practices of manufacturing SCM. The additional research is required to be carried out to study whether these ICT practices are unvaryingly applicable to other industries. Extension of this research can be made to check if companies operating in other industries such as service, pharmaceutical, etc. originate the same findings. This may enhance the external validity of the study and improve the accuracy of the parameter examined.

Since there is insignificant relationship between SCP and FP, there is possibility of existence of mediating or moderating variable between these relationships. Further research could be carried out to test the moderation and/or mediation effect between SCP and FP. Extending this research study to the firms operating in other sectors can enhance the external validity of the study and improve the accuracy of parameters examined. Since the researchers are convinced that this study presents a picture of how IT, IS, SCI, and SCP enhance manufacturing firm's performance. The identified constructs and proposed model can be used by academicians as a basis for undertaking further empirical research that tests IT and IS with other factors throughout the supply chain network. Other than that, a major limitation of the present investigation is that the data were solely from Malaysia. This may reduce the generalizability of the findings regarding other developing countries due to each country different characteristics and geographic features. For example, the geographical representation limitation in a Malaysian context is constrained, as the data were obtained solely from manufacturing firms in the highly industrial active states areas in Selangor, Melaka, and Johor. Future research should be conducted in other states and in the other parts of Malaysia that include areas in East Peninsular Malaysia to discern the generalizability of this study's findings.

\section{Acknowledgements}

Our special thanks to Universiti Teknologi MARA, Cawangan Selangor, Malaysia and Institute of Research Management \& Innovation, UiTM Shah Alam. This study draws from FRGS Research Grant awarded by the KPT; Project code: 600IRMI/FRGS 5/3 (434/2019).

\section{References}

Akmal, A. O., Sofiah, A. R., Sundram, V. P. K., Bhatti, M. A., 2015. Modelling marketing resources, procurement process coordination and firm performance in the Malaysian building construction industry. Engineering, Construction and Architectural Management 22, 644-668.

Akmal, A. O., Sundram, V. P. K., Nazura, M. B. S., Atikah, S. B., 2016. The relationship between supply chain integration, just-in-time and logistics performance: A supplier's perspective on the automotive industry in Malaysia. International Journal of Supply Chain Management 5, 44-51.

Akkermans, H. A., Bogerd, P., Yücesan, E., Van Wassenhove, L. N., 2003. The impact of ERP on supply chain management: Exploratory findings from a European Delphi study. European Journal of Operational Research 146, 284-301.

Anand, N., Grover, N., 2015. Measuring retail supply chain performance: Theoretical model using key performance indicators (KPIs). Benchmarking: An International Journal 22, 135-166.

Anderson, J. C., Narus, J. A., Wouters, M., 2014. Tiebreaker selling: How nonstrategic suppliers can help customers solve important problems. Harvard Business Review 92, 90-96.

Banker, R. D., Bardhan, I. R., Chang, H., Lin, S., 2006. Plant information systems, manufacturing capabilities, and plant performance. MIS Quarterly 30, 315-337. 
Barlow, A., Li, F., 2005. Online value network linkages: Integration, information sharing and flexibility. Electronic Commerce Research and Applications 4, 100-112.

Barney, J. B., 2000. Firm resources and sustained competitive advantage. In: Baum, J., Dobbin, F. (Eds), Economics Meets Sociology in Strategic Management, Emerald, Bingley, UK.

Barney, J. B., Clark, D. N., 2007. Resource-Based Theory: Creating and Sustaining Competitive Advantage. Oxford University Press, Oxford, UK.

Bender, P. S., 2000. Debunking five supply chain myths. Supply Chain Management Review 2, 52-58.

Boyer, K. K., Pagell, M., 2000. Measurement issues in empirical research: Improving measures of operations strategy and advanced manufacturing technology. Journal of Operations Management 18, 361-374.

Brooks, M. R., 2000. Performance evaluation of carriers by North American companies. Transport Reviews 20, 205-218.

Carr, A. S., Smeltzer, L. R., 2002. The relationship between information technology use and buyer-supplier relationships: An exploratory analysis of the buying firm's perspective. IEEE Transactions on Engineering Management 49, 293-304.

Chan, F. T., Qi, H. J., 2003. Feasibility of performance measurement system for supply chain: A process-based approach and measures. Integrated Manufacturing Systems 14, 179-190.

Chen, I. J., Paulraj, A., 2004. Understanding supply chain management: Critical research and a theoretical framework. International Journal of Production Research 42, 131-163.

Chen, S. C., Shing-Han, L., Chien-Yi, L., 2011. Recent related research in technology acceptance model: A literature review. Australian Journal of Business and Management Research 1, 124-127.

Cohen, J., 1992. A power primer. Psychological Bulletin 112, 155-159.

Collins, J. D., Hitt, M. A., 2006. Leveraging tacit knowledge in alliances: The importance of using relational capabilities to build and leverage relational capital. Journal of Engineering and Technology Management 23, 147-167.

Collins, J. D., Worthington, W. J., Reyes, P. M., Romero, M., 2010. Knowledge management, supply chain technologies, and firm performance. Management Research Review 33, 947-960.

Combs, J. G., Crook, T. R., Shook, C. L., 2005. The dimensionality of organizational performance and its implications for strategic management research. In: Ketchen, D., Bergh, D. (Eds), Research Methodology in Strategy and Management. Emerald, Bingley, UK.

Conner, K. R., 1991. A historical comparison of resource-based theory and five schools of thought within industrial organization economics: Do we have a new theory of the firm? Journal of Management 17, 121-154.

Crook, T. R., Ketchen Jr, D. J., Combs, J. G., Todd, S. Y., 2008. Strategic resources and performance: A meta-analysis. Strategic Management Journal 29, 1141-1154.

Donk, D. P. V., Akkerman, R., Vaart, T. V. D., 2008. Opportunities and realities of supply chain integration: The case of food manufacturers. British Food Journal 110, 218-235.

Fawcett, S. E., Osterhaus, P., Magnan, G. M., Brau, J. C., McCarter, M. W., 2007. Information sharing and supply chain performance: The role of connectivity and willingness. Supply Chain Management: An International Journal 12, 358368.

Fiala, P., 2005. Information sharing in supply chains. Omega 33, 419-423.

Flynn, B. B., Huo, B., Zhao, X., 2010. The impact of supply chain integration on performance: A contingency and configuration approach. Journal of Operations Management 28, 58-71.

Fornell, C., Johnson, M. D., Anderson, E. W., Cha, J., Bryant, B. E., 1996. The American customer satisfaction index: Nature, purpose, and findings. Journal of Marketing 60, 7-18.

Fornell, C., Larcker, D. F., 1981. Evaluating structural equation models with unobservable variables and measurement error. Journal of Marketing Research 18, 39-50.

Forster, P. W., Regan, A. C., 2001. Electronic integration in the air cargo industry: An information processing model of on-time performance. Transportation Journal 40, 46-61.

Frohlich, M. T., Westbrook, R., 2001. Arcs of integration: An international study of supply chain strategies. Journal of Operations Management 19, 185-200.

Garengo, P., Bititci, U., 2007. Towards a contingency approach to performance measurement: An empirical study in Scottish SMEs. International Journal of Operations \& Production Management 27, 802-825.

Graham, G., Hardaker, G., 2000. Supply-chain management across the Internet. International Journal of Physical Distribution \& Logistics Management 30, 286-295.

Green, K. W., Inman, R. A., 2005. Using a just-in-time selling strategy to strengthen supply chain linkages. International Journal 
of Production Research 43, 3437-3453.

Grover, V., Malhotra, M. K., 1997. Business process reengineering: A tutorial on the concept, evolution, method, technology and application. Journal of Operations Management 15, 193-213.

Gunasekaran, A., Kobu, B., 2007. Performance measures and metrics in logistics and supply chain management: A review of recent literature (1995-2004) for research and applications. International Journal of Production Research 45, 2819-2840.

Hahn, C. K., Watts, C. A., Kim, K. Y., 1990. The supplier development program: A conceptual model. Journal of Purchasing and Materials Management 26, 2-7.

Hair, J. F., Hult, G. T. M., Ringle, C. M., Sarstedt, M., 2016. A Primer on Partial Least Squares Structural Equation Modeling (PLS-SEM). SAGE Publications, Los Angeles, CA.

Hair, J. F., Sarstedt, M., Hopkins, L., Kuppelwieser, V. G., 2014. Partial least squares structural equation modeling (PLS-SEM): An emerging tool in business research. European Business Review 26, 106-121.

Hair Jr, J. F., Sarstedt, M., Ringle, C. M., Gudergan, S. P., 2017. Advanced Issues in Partial Least Squares Structural Equation Modeling. SAGE, Los Angeles, CA.

Hollander, A. S., Denna, E. L., Cherrington, J. O., 1999. Accounting, Information Technology, and Business Solutions. McGraw-Hill, Boston, MA.

Hult, G. T. M., Ketchen, D. J., Slater, S. F., 2004. Information processing, knowledge development, and strategic supply chain performance. Academy of Management Journal 47, 241-253.

Ibrahim, A. R., Zolait, A. H., Sundram, V. P., 2010. Supply chain management practices and firm performance: An empirical study of the electronics industry in Malaysia. International Journal of Technology Diffusion 1, 48-55.

Jain, V., Wadhwa, S., Deshmukh, S. G., 2009. Select supplier-related issues in modelling a dynamic supply chain: Potential, challenges and direction for future research. International Journal of Production Research 47, 3013-3039.

Jharkharia, S., Shankar, R., 2005. IT-enablement of supply chains: Understanding the barriers. Journal of Enterprise Information Management 18, 11-27.

Kehoe, D. F., Boughton, N. J., 2001. New paradigms in planning and control across manufacturing supply chains-The utilisation of Internet technologies. International Journal of Operations \& Production Management 21, 582-593.

Ketchen, D. J., Giunipero, L. C., 2004. The intersection of strategic management and supply chain management. Industrial Marketing Management 33, 51-56.

Kim, D., Lee, R. P., 2010. Systems collaboration and strategic collaboration: Their impacts on supply chain responsiveness and market performance. Decision Sciences 41, 955-981.

Kim, S. W., 2009. An investigation on the direct and indirect effect of supply chain integration on firm performance. International Journal of Production Economics 119, 328-346.

Lambert, D. M., Cooper, M. C., 2000. Issues in supply chain management. Industrial Marketing Management 29, 65-83.

Lambert, D. M., Cooper, M. C., Pagh, J. D., 1998. Supply chain management: Implementation issues and research opportunities. The International Journal of Logistics Management 9, 1-20.

Lee, H. L., Padmanabhan, V., Whang, S., 1997. Information distortion in a supply chain: The bullwhip effect. Management Science 43, 546-558.

Lee, H. L., So, K. C., Tang, C. S., 2000. The value of information sharing in a two-level supply chain. Management Science 46, 626-643.

Lee, H. L., Whang, S., 2000. Information sharing in a supply chain. International Journal of Manufacturing Technology and Management 1, 79-93.

Li, G., Yang, H., Sun, L., Sohal, A. S., 2009. The impact of IT implementation on supply chain integration and performance. International Journal of Production Economics 120, 125-138.

Li, J., Sikora, R., Shaw, M. J., Tan, G. W., 2006a. A strategic analysis of inter organizational information sharing. Decision Support Systems 42, 251-266.

Li, N. I., 2015. The impact of supply chain integration on operation performance the moderating role of IT competence. Management Science and Engineering 9, 40-45.

Li, S., Lin, B., 2006. Accessing information sharing and information quality in supply chain management. Decision Support Systems 42, 1641-1656.

Li, S., Ragu-Nathan, B., Ragu-Nathan, T. S., Rao, S. S., 2006b. The impact of supply chain management practices on competitive advantage and organizational performance. Omega 34, 107-124.

Lun, Y. H. V., Wong, C. W. Y., Lai, K. H., Cheng, T. C. E., 2008. Institutional perspective on the adoption of technology for the 
security enhancement of container transport. Transport Reviews 28, 21-33.

Lyons, A., Coleman, J., Kehoe, D., Coronado, A., 2004. Performance observation and analysis of an information re-engineered supply chain: A case study of an automotive firm. Industrial Management \& Data Systems 104, 658-666.

Madlberger, M., 2009. What drives firms to engage in interorganizational information sharing in supply chain management? International Journal of e-Collaboration 5, 18-42.

Makris, S., Xanthakis, V., Mourtzis, D., Chryssolouris, G., 2008. On the information modeling for the electronic operation of supply chains: A maritime case study. Robotics and Computer-Integrated Manufacturing 24, 140-149.

MAMPU [Malaysian Administrative Modernisation and Management Planning Unit], 2019. Annual Report 2018, Department of Prime Minister, Putrajaya, Malaysia.

McIvor, R., 2000. A practical framework for understanding the outsourcing process. Supply Chain Management: An International Journal 5, 22-36.

McIvor, R., Humphreys, P., Huang, G., 2000. Electronic commerce: Re-engineering the buyer-supplier interface. Business Process Management Journal 6, 122-138.

MIDA [Malaysian Investment Development Authority], 2018. Investment in the Manufacturing Sector-Policies, Incentives and Facilities, Ministry of International Trade and Industry, Kuala Lumpur, Malaysia.

Miller, C. C., Washburn, N. T., Glick, W. H., 2013. Perspective-The myth of firm performance. Organization Science 24, 948964.

Milliken, A. L., 2001. Key ingredients of successful performance metrics in the supply chain. The Journal of Business Forecasting Methods and Systems 20, 23-28.

Narasimhan, R., Kim, S. W., 2002. Effect of supply chain integration on the relationship between diversification and performance: Evidence from Japanese and Korean firms. Journal of Operations Management 20, 303-323.

Neely, A., Gregory, M., Platts, K., 2005. Performance measurement system design: A literature review and research agenda. International Journal of Operations \& Production Management 25, 1228-1263.

Ngai, E. W. T., Chau, D. C. K., Chan, T. L. A., 2011. Information technology, operational, and management competencies for supply chain agility: Findings from case studies. The Journal of Strategic Information Systems 20, 232-249.

Nguyen, T. H., Newby, M., Macaulay, M. J., 2015. Information technology adoption in small business: Confirmation of a proposed framework. Journal of Small Business Management 53, 207-227.

Paulraj, A., Chen, I. J., 2007. Strategic buyer-supplier relationships, information technology and external logistics integration. Journal of Supply Chain Management 43, 2-14.

Power, D., 2005. Supply chain management integration and implementation: A literature review. Supply Chain Management: An International Journal 10, 252-263.

Prahinski, C., Benton, W. C., 2004. Supplier evaluations: Communication strategies to improve supplier performance. Journal of Operations Management 22, 39-62.

Prajogo, D., Olhager, J., 2012. Supply chain integration and performance: The effects of long-term relationships, information technology and sharing, and logistics integration. International Journal of Production Economics 135, 514-522.

Pramatari, K., 2007. Collaborative supply chain practices and evolving technological approaches. Supply Chain Management: An International Journal 12, 210-220.

Rai, A., Patnayakuni, R., Seth, N., 2006. Firm performance impacts of digitally enabled supply chain integration capabilities. MIS Quarterly 30, 225-246.

Richard, P. J., Devinney, T. M., Yip, G. S., Johnson, G., 2009. Measuring organizational performance: Towards methodological best practice. Journal of Management 35, 718-804.

Sahin, F., Robinson, E. P., 2002. Flow coordination and information sharing in supply chains: Review, implications, and directions for future research. Decision Sciences 33, 505-536.

Sarosa, S., Zowghi, D., 2005. Information technology adoption process within Indonesian SMEs: An empirical study. Proceedings of 16th Australasian Conference on Information Systems, Sydney, Australia.

Schoenherr, T., Swink, M., 2012. Revisiting the arcs of integration: Cross-validations and extensions. Journal of Operations Management 30, 99-115.

Sezen, B., 2008. Relative effects of design, integration and information sharing on supply chain performance. Supply Chain Management: An International Journal 13, 233-240.

Shore, B., Venkatachalam, A. R., 2003. Evaluating the information sharing capabilities of supply chain partners: A fuzzy logic model. International Journal of Physical Distribution \& Logistics Management 33, 804-824. 
Soliman, F., Youssef, M., 2001. The impact of some recent developments in e-business on the management of next generation manufacturing. International Journal of Operations \& Production Management 21, 538-564.

Stonebraker, P. W., Liao, J., 2006. Supply chain integration: Exploring product and environmental contingencies. Supply Chain Management: An International Journal 11, 34-43.

Subramani, M., 2004. How do suppliers benefit from information technology use in supply chain relationships?. MIS Quarterly 28, 45-73.

Sundram, V. P. K, Atikah, S. B., Akmal, A. O., Zarina, A. M., 2017. Green supply chain management practices in Malaysia manufacturing industry. International Journal of Supply Chain Management 6, 89-95.

Sundram, V. P. K., Atikah, S. B., Chandran, V. G. R., 2016a. Supply Chain Management: Principles, Measurement and Practice. University of Malaya Press, Kuala Lumpur, Malaysia.

Sundram, V. P. K., Atikah, S. B., Zarina, A. M., Zolait, A. H., 2018a. The effect of supply chain information management and information system infrastructure: The mediating role of supply chain integration towards manufacturing performance in Malaysia. Journal of Enterprise Information Management 31, 751-770.

Sundram, V. P. K., Chandran, V. G. R., Atikah, S. B., Rohani, M., Nazura, M. S., Akmal, A. O., Krishnasamy, T., $2016 b$. Research Methodology: Tools, Methods and Techniques. Malaysia Logistic \& Supply Chain Association, Selangor, Malaysia.

Sundram, V. P. K., Chandran, V. G. R., Bhatti, M. A., 2016c. Supply chain practices and performance: The indirect effects of supply chain integration. Benchmarking: An International Journal 23, 1445-1471.

Sundram, V. P. K., Chandran, V. G. R., Ibrahim, A. R., 2011. Supply chain management practices in the electronics industry in Malaysia: Consequences for supply chain performance. Benchmarking: An International Journal 18, 834-855.

Sundram V. P. K., Rajagopal P., Atikah S. B. Subramaniam, G., 2018b. The role of supply chain integration on green practices and performance in a supply chain context. A conceptual approach to future research. International Journal of Supply Chain Management: An International Journal 7, 95-104.

Swink, M., Narasimhan, R., Wang, C., 2007. Managing beyond the factory walls: Effects of four types of strategic integration on manufacturing plant performance. Journal of Operations Management 25, 148-164.

Tan, K. C., Kannan, V. R., Handfield, R. B., 1998. Supply chain management: Supplier performance and firm performance. Journal of Supply Chain Management 34, 2-9.

Tan, K. S., Choy Chong, S., Lin, B., Cyril Eze, U., 2009. Internet-based ICT adoption: Evidence from Malaysian SMEs. Industrial Management \& Data Systems 109, 224-244.

Teece, D. J., 2012. Dynamic capabilities: Routines versus entrepreneurial action. Journal of Management Studies 49, 13951401.

Tenenhaus, M., Vinzi, V. E., Chatelin, Y. M., Lauro, C., 2005. PLS path modeling. Computational Statistics \& Data Analysis 48, 159-205.

Thong, J. Y. L., Yap, C. S., 1995. CEO characteristics, organizational characteristics and information technology adoption in small businesses. Omega 23, 429-442.

Thun, J. H., 2010. Angles of integration: An empirical analysis of the alignment of internet-based information technology and global supply chain integration. Journal of Supply Chain Management 46, 30-44.

Trkman, P., Groznik, A., 2006. Measurement of supply chain integration benefits. Interdisciplinary Journal of Information, Knowledge \& Management 1, 37-45.

Van der Vaart, T., van Donk, D. P., 2008. A critical review of survey-based research in supply chain integration. International Journal of Production Economics 111, 42-55.

Venkatraman, N., Ramanujam, V., 1986. Measurement of business performance in strategy research: A comparison of approaches. Academy of Management Review 11, 801-814.

Vickery, S. K., Jayaram, J., Droge, C., Calantone, R., 2003. The effects of an integrative supply chain strategy on customer service and financial performance: An analysis of direct versus indirect relationships. Journal of Operations Management 21, 523-539.

Whalen, J., 2002. Weighing in on performance measurements. Logistics Management and Distribution 41, 33-37.

Wong, C. W. Y., Lai, K. H., Ngai, E. W. T., 2009. The role of supplier operational adaptation on the performance of IT-enabled transport logistics under environmental uncertainty. International Journal of Production Economics 122, 47-55.

Wu, W. M., 2009. An approach for measuring the optimal fleet capacity: Evidence from the container shipping lines in Taiwan. International Journal of Production Economics 122, 118-126. 
Wynstra, F., Axelsson, B., Van Weele, A., 2000. Driving and enabling factors for purchasing involvement in product development. European Journal of Purchasing \& Supply Management 6, 129-141.

Zailani, S., Rajagopal, P., 2005. Supply chain integration and performance: US versus East Asian companies. Supply Chain Management: An International Journal 10, 379-393.

Zhang, X., van Donk, D. P., van der Vaart, T., 2011. Does ICT influence supply chain management and performance? A review of survey-based research. International Journal of Operations \& Production Management 31, 1215-1247.

Zhao, X., Huo, B., Flynn, B. B., Yeung, J. H. Y., 2008. The impact of power and relationship commitment on the integration between manufacturers and customers in a supply chain. Journal of Operations Management 26, 368-388.

Zhao, X., Huo, B., Selen, W., Yeung, J. H. Y., 2011. The impact of internal integration and relationship commitment on external integration. Journal of Operations Management 29, 17-32.

Zolait, A. H., Ibrahim, A. R., Chandran, V. G. R., Sundram, V. P. K., 2010. Supply chain integration: An empirical study on manufacturing industry in Malaysia. Journal of Systems and Information Technology 12, 210-221. 